\title{
DESKRIPSI HASIL BELAJAR MATEMATIKA PESERTA DIDIK MENGGUNAKAN MODEL PEMBELAJARAN PROBLEM BASED LEARNING (PBL) PADA KELAS VIII
}

\author{
Hesti Wulandari ${ }^{1}$, Hanifah ${ }^{2}$, Syafdi Maizora ${ }^{3}$, \\ ${ }^{1,2,3}$ Prodi Pendidikan Matematika JPMIPA FKIP Universitas Bengkulu \\ email : ${ }^{1}$ hestiwulandari211@gmail.com, ${ }^{2}$ Hanifah@unib.ac.id., \\ 3 syafdiichiemaizora@unib.ac.id
}

\begin{abstract}
ABSTRAK
Penelitian ini bertujuan untuk mendeskripsikan hasil belajar matematika peserta didik kelas VIII SMP Negeri 2 Kota Bengkulu dengan model pembelajaran Problem Based Learning (PBL). Penelitian ini merupakan penelitian deskriptif (Descriptive Research). Sampel diambil dengan menggunakan teknik purposive sampling, sampel dalam penelitian ini adalah peserta didik kelas VIII F SMP Negeri 2 Kota Bengkulu Tahun Ajaran 2017/2018 yang berjumlah 34 orang peserta didik. Instrumen yang digunakan untuk pengumpulan data dalam penelitian ini adalah lembar tes dan Lembar Kerja Peserta Didik (LKPD) pada materi lingkaran. Berdasarkan hasil deskriptif hasil belajar matematika peserta didik menggunakan model pembelajaran Problem Based Learning menunjukkan bahwa hasil belajar peserta didik menjadi lebih meningkat. Hal ini ditunjukkan dengan rata-rata hasil nilai LKPD menggunakan model pembelajaran Problem Based Learning yaitu 89,63 dan rata-rata nilai tes yaitu 84,56.
\end{abstract}

Kata Kunci : Deskriptif, Hasil Belajar Belajar, Problem Based Learning

\begin{abstract}
The aim of this research was to describe the results of learning mathematics students VIII grade SMP Negeri 2 Kota Bengkulu with Problem Based Learning (PBL) learning model. This research was a descriptive research (Descriptive Research). The sample was taken by using purposive sampling technique, the sample of this research was the students of class VIII F SMP Negeri 2 Kota Bengkulu academic year 2017/2018 with 34 students. The instruments that used for data collection in this research were test sheet and Student Worksheet on the circle material. Based on the results of descriptive mathematics learning outcomes of students using Problem Based Learning the learning outcomes of students were more increased. This research was done by avarage value of LKPD using Problem Based Learning is 89,63 and the avarage test score 84,56.
\end{abstract}

Keywords: Descriptive, Learning Outcomes Learning, Problem Based Learning

\section{PENDAHULUAN}

Pembelajaran adalah proses interaksi antara peserta didik, pendidik, dan sumber belajar pada suatu lingkungan belajar (Hosnan, 2016:4). Proses interaksi itu meliputi kegiatankegiatan yang dilaksanakan untuk mencapai suatu tujuan yang tidak lain merupakan acuan dalam pembelajaran. Adapun ketercapaian tujuan pembelajaran dapat dilihat melalui hasil belajar yang diperoleh peserta didik. Hasil belajar akan tercapai dengan baik dan maksimal apabila proses pembelajaran dilaksanakan dengan baik dan maksimal pula.

Matematika merupakan mata pelajaran yang wajib dipelajari oleh semua peserta didik sejak SD hingga Perguruan Tinggi. Melalui pembelajaran matematika diharapkan peserta didik dapat menumbuhkan kemampuan berfikir 
kritis, logis, sistematis, dan cermat dalam memecahkan masalah. Meskipun pembelajaran matematika merupakan salah satu mata pelajaran yang masih dianggap sulit dipahami oleh peserta didik (Soedjadi, 2000:43).

Pada pembelajaran matematika di SMP sering dijumpai peserta didik yang mengalami kesulitan dalam memahami materi yang diajarkan sehingga mengakibatkan hasil belajar yang diperoleh rendah. Kesulitan yang dihadapi peserta didik dalam memahami materi matematika bisa disebabkan dari beberapa faktor, yaitu faktor internal dan faktor eksternal. Salah satu faktor yang berasal dari luar diri peserta didik yang mempengaruhi hasil belajar peserta didik adalah proses pembelajaran matematika yang kurang tepat.

Penulis telah melakukan survei awal disalah satu sekolah menengah pertama di Kota Bengkulu yaitu SMPN 2 Kota Bengkulu, wawancara dilakukan pada 8 Januari 2018 dengan salah satu guru matematika kelas VIII di SMP Negeri 2 Kota Bengkulu. Hasil wawancara teridentifikasi bahwa dalam pembelajaran matematika peserta didik kelas VIII hanya $77 \%$ yang mencapai standar KKM yaitu 75 .

Hasil pengamatan dalam pembelajaran ditemukan masalah dalam proses pembelajaran seperti: 1) peserta didik kurang memiliki rasa ingin tahu; sehinga masih jarang peserta didik yang mengajukan pertanyaan mengenai materi yang sedang dipelajari; 2) peserta didik belum dapat menyelesaikan soal-soal yang berkaitan dengan permasalahan nyata; 3) peserta didik masih kesulitan dalam menggambar benda konkrit dari permasalahan yang diberikan; 4) peserta didik masih kesulitan menyelesaikan soal aplikasi. Dalam menyelesaikan persoalan yang menyangkut materi lingkaran seringnya peserta didik hanya bermodal memasukkan angka ke rumus tanpa diikuti pemahaman konsep yang mendalam. Peserta didik hanya mampu mengerjakan soal-soal yang dicontohkan oleh guru. Apabila diberikan soal yang berbeda dari contoh, peserta didik kurang mampu menyelesaikannya. Hal ini menunjukkan bahwa pemahaman konsep peserta didik terhadap materi yang diajarkan masih kurang, sehingga berdampak pada hasil belajar matematika peserta didik yang kurang memuaskan.

Model pembelajaran yang dapat mengarahkan peserta didik untuk mengkoneksikan pengetahuan yang telah dimiliki dengan materi yang akan dipelajari merupakan salah satu model yang dapat diterapkan dalam pembelajaran matematika. Oleh karena itu, dalam pelaksanaan pembelajaran matematika diperlukan langkahlangkah sistematis yakni dengan menggunakan model pembelajaran yang cocok agar peserta didik dapat berpikir logis, kritis, dan inovatif serta dapat menciptakan suasana belajar yang menyenangkan. Pembelajaran juga harus bermanfaat bagi peserta didik dan lebih menekankan keterlibatan peserta didik secara optimal. Salah satu cara yang dapat dipakai adalah dengan menerapkan model pembelajaran Problem Based Learning.

Kurikulum yang digunakan di SMP Negeri 2 Kota Bengkulu adalah Kurikulum 2013. Prinsip utama dalam pengembangan kurikulum 2013 adalah berdasarkan model kurikulum berbasis kompetensi dengan standar kompetensi lulusan yang ditetapkan untuk satu satuan pendidikan, jenjang pendidikan dan program pendidikan. Sehingga, setiap peserta didik dituntut aktif selama proses pembelajaran berlangsung. Implementasi kurikulum 2013 dalam pembelajaran dengan pendekatan saintifik adalah proses pembelajaran yang 
dirancang sedemikian rupa agar peserta didik secara aktif mengonstruk konsep, hukum atau prinsip melalui tahap tahap mengamati, menanya, mengumpulkan data, mengasosiasi, dan mengkomunikasikan konsep, hukum dan prinsip yang ditemukan. Proses pembelajaran di SMP Negeri 2 sudah menerapkan pembelajaran dengan pendekatan saintifik. Pendekatan saintifik dimaksudkan untuk memberikan pemahaman kepada peserta didik dalam mengenal, memahami berbagai materi menggunakan pendekatan ilmiah bahwa informasi bisa berasal dari mana saja, kapan saja, tidak bergantung dari informasi searah dari guru.

Model pembelajaran Problem Based Learning dengan pendekatan saintifik merupakan model pembelajaran yang dianggap dapat membuat peserta didik lebih aktif, mendorong kerja sama antar peserta didik sehingga dapat meningkatkan hasil belajar matematika peserta didik. Oleh karena itu diperlukan model pembelajaran yang dapat meningkatkan keaktifan peserta didik dalam belajar, dengan tujuan dapat meningkatkan hasil belajar peserta didik.

Model pembelajaran yang dapat menyelesaikan permasalahan di atas salah satunya yaitu Problem Based Learning (PBL). Menurut Sani (2015:127) Model Problem Based Learning (PBL) merupakan model pembelajaran yang penyampaiannya dilakukan dengan cara menyajikan suatu permasalahan, mengajukan pertanyaan-pertanyaan, memfasilitasi penyelidikan, dan membuka dialog. Permasalahan yang dikaji hendaknya merupakan permasalahan kontekstual yang ditemukan oleh peserta didik dalam kehidupan sehari-hari. PBL menjadi sebuah pendekatan pembelajaran yang berusaha menerapkan masalah yang terjadi dalam dunia nyata sebagai konteks bagi para peserta didik dalam berlatih bagaimana cara berfikir kritis dan mendapatkan keterampilan dalam pemecahan masalah, serta untuk mendapatkan pengetahuan sekaligus konsep yang penting dari materi yang diajarkan. (Sani, 2015:127)

Menurut Sani (2015:157) langkahlangkah model pembelajaran PBL yaitu:

1. Menjelaskan tujuan pembelajaran dan aktivitas yang akan dilakukan, menyajikan permasalahan, memaparkan kebutuhan logistik untuk pembelajaran, memotivasi peserta didik untuk terlibat aktif.

2. Membantu peserta didik dalam mendefinisikan dan mengorganisasikan tugas belajar/penyelidikan untuk penyelesaian masalah, mencoba membuat hipotesis atas masalah yang ditemukan.

3. Mendorong peserta didik untuk mengumpulkan informasi sebanyakbanyaknya, memperoleh informasi yang tepat, melaksanakan penyelidikan, dan mencari penjelasan solusi.

4. Membantu peserta didik menganalisis data yang telah terkumpul, menyesuaikan data dengan masalah yang telah dirumuskan, Peserta didik memberi argumen terhadap jawaban pemecahan masalah, merencanakan produk yang tepat dan relevan, seperti laporan, rekaman video, dan sebagainya untuk keperluan penyampaian hasil.

5. Guru dan peserta didik menganalisis dan mengevaluasi terhadap pemecahan masalah yang dipresentasikan setiap kelompok, membantu peserta didik melakukan refleksi terhadap penyelidikan dan proses yang mereka lakukan.

6. Penyajian hasil diskusi kelompok.

Bahan diskusi yang diberikan kepada peserta didik berupa LKPD. Proses 
pembelajaran model pembelajaran Problem Based Learning dengan pendekatan saintifik :

\begin{tabular}{|c|c|}
\hline $\begin{array}{l}\text { Tahapan } \\
\text { Kegiatan }\end{array}$ & Kegiatan Pembelajaran \\
\hline $\begin{array}{l}\text { Memberikan } \\
\text { orientasi } \\
\text { permasalahan } \\
\text { kepada peserta } \\
\text { didik. }\end{array}$ & $\begin{array}{l}\text { 1. Guru menjelaskan tujuan } \\
\text { pembelajara dan aktivitas } \\
\text { yang akan } \\
\text { dilakukan.(Mengamati) } \\
\text { 2. Guru mengajukan suatu } \\
\text { masalah sebagai langkah } \\
\text { awal pembelajaran. } \\
\text { Masalah yang diajukan } \\
\text { biasanya masalah dalam } \\
\text { dunia nyata. (Menanya). } \\
\text { 3. Guru memotivasi peserta } \\
\text { didik untuk terlibat aktif } \\
\text { dalam pemecahan } \\
\text { masalah. (Mengamati) }\end{array}$ \\
\hline $\begin{array}{l}\text { Mengorganisa } \\
\text { sikan peserta } \\
\text { didik untuk } \\
\text { melakukan } \\
\text { penyelidikan. }\end{array}$ & $\begin{array}{l}\text { 1. Peserta didik dibagi } \\
\text { menjadi } 7 \text { kelompok } \\
\text { secara } \\
\text { (mengumpulkan } \\
\text { informasi) } \\
\text { 2. Peserta didik diberikan } \\
\text { LKPD untuk dikerjakan } \\
\text { secara berkelompok. } \\
\text { (mengumpulkan } \\
\text { informasi) } \\
\text { 3. Guru membantu peserta } \\
\text { didik dalam } \\
\text { mendefinisikan } \\
\text { mengorganisasikan tugas } \\
\text { belajar/penyelidikan } \\
\text { untuk penyelesaian } \\
\text { masalah. (Mengamati) }\end{array}$ \\
\hline $\begin{array}{l}\text { Pelaksanaan } \\
\text { investigasi }\end{array}$ & $\begin{array}{l}\text { 1. Mendorong peserta didik } \\
\text { untuk mengumpulkan } \\
\text { informasi sebanyak- } \\
\text { banyaknya. } \\
\text { (mengumpulkan } \\
\text { informasi) } \\
\text { 2. Peserta didik melakukan } \\
\text { penyelidikan dan } \\
\text { investigasi dalam rangka } \\
\text { menyelesaikan masalah. } \\
\text { (mengumpulkan } \\
\text { informasi) } \\
\text { 3. Guru membombing setiap } \\
\text { kelompok agar } \\
\text { menemukan jawaban }\end{array}$ \\
\hline
\end{tabular}

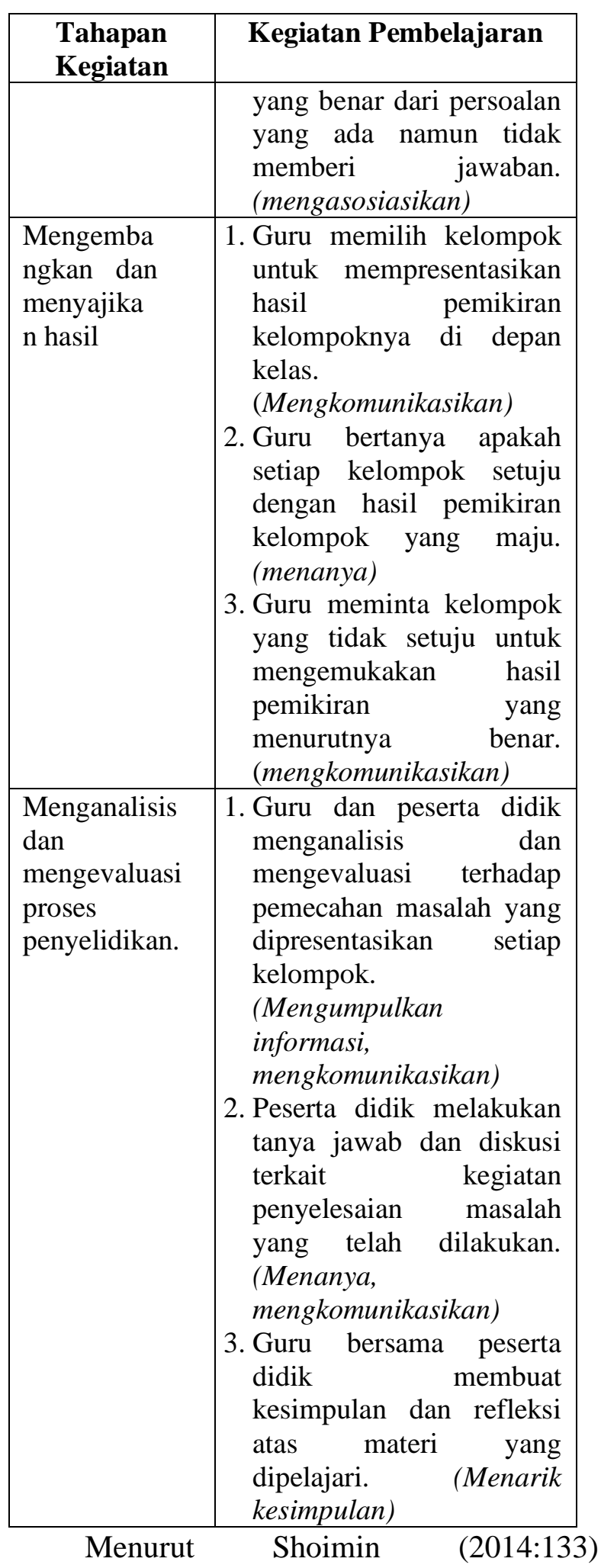

kelemahan model pembelajaran Problem Based Learning (PBL): (a) Tidak dapat diterapkan untuk setiap materi pembelajaran; (b) Dalam suatu kelas yang memiliki tingkat keragaman

Hesti, Hanifah, Syafdi 
peserta didik akan terjadi kesulitan dalam pembagian tugas.

Manfaat penelitian ini bagi peserta didik yaitu sebagai upaya untuk memotivasi peserta didik agar antusias dan aktif dalam proses pembelajaran matematika serta meningkatkan hasil belajar matematika peserta didik; Manfaat bagi guru yaitu sebagai bahan pertimbangan guru dalam pemilihan model pembelajaran matematika yang tepat sehingga tujuan pembelajaran dapat tercapai.

\section{METODE}

Penelitian ini merupakan penelitian deskriptif (Descriptive Research) yang dilakukan di SMP Negeri 2 Kota Bengkulu.

Populasi dalam penelitian ini adalah peserta didik Kelas VIII SMP Negeri 2 Kota Bengkulu semester genap tahun pelajaran 2017/2018. Teknik pengambilan sampel dalam penelitian ini purposive sampling yaitu teknik pengambilan sampel dengan pertimbangan tertentu (Lestari \& Yudhanegara, 2015:110). Pertimbangan pengambilan sampel ini adalah nilai rata-rata matematika peserta didik pada ujian semester ganjil tahun ajaran 2017/2018 yang relatif sama, sehingga diambil kelas VIII F sebagai kelas sampel.

Pada penelitian ini instrumen yang digunakan adalah tes akhir (posttest) dan LKPD. Soal tes berupa soal esai. Soal posttest tersebut diujicobakan terlebih dahulu di kelas uji coba dan dianalisis untuk melihat kevalidan soal, reliabilitas soal, daya pembeda soal, dan taraf kesukaran soal.

Dalam penelitian ini data dianalisis berdasarkan pengamatan dilapangan berdasarkan data yang diperoleh dari wawancara, observasi, dan dokumentasi kemudian disusun dan ditarik kesimpulan.

\section{HASIL DAN PEMBAHASAN}

Penelitian terdiri dari 7 pertemuan yaitu 6 pertemuan proses pembelajaran dan 1 pertemuan posttest. Soal posttest sebelumnya telah divalidasi oleh dua orang validator ahli. Kemudian setelah soal-soal valid, soal tersebut diuji cobakan ke kelas uji coba. Hasil uji coba dianalisis menggunakan uji kevalidan, reliabilitas, tingkat kesukaran dan daya beda soal. Tabel 1 menunjukkan hasil analisis soal uji coba:

Tabel 1. Hasil Uji Coba Instrumen

\begin{tabular}{|c|c|c|c|c|}
\hline No & Validitas & $\begin{array}{c}\text { Reliabi } \\
\text { litas }\end{array}$ & $\begin{array}{c}\text { Taraf } \\
\text { Kesukaran }\end{array}$ & $\begin{array}{l}\text { Daya } \\
\text { Beda }\end{array}$ \\
\hline 1 & 0,42 & \multirow[t]{9}{*}{0,703} & 0,61 & 0,21 \\
\hline 2 & 0,60 & & 0,75 & 0,20 \\
\hline 3 & 0,64 & & 0,62 & 0,20 \\
\hline 4 & 0,52 & & 0,77 & 0,23 \\
\hline 5 & 0,47 & & 0,79 & 0,20 \\
\hline 6 & 0,61 & & 0,77 & 0,53 \\
\hline 7 & 0,75 & & 0,67 & 0,22 \\
\hline 8 & 0,45 & & 0,74 & 0,20 \\
\hline 9 & 0,54 & & 0,69 & 0,23 \\
\hline
\end{tabular}

Berdasarkan hasil pada tabel 1. dapat diketahui bahwa soal nomor $1,3,4,5,6,7,8$ dan 9 dapat dijadikan soal posttest. Hal ini karena soal-soal tersebut telah sesuai dengan kriteria validitas, reliabilitas, tingkat kesukaran dan daya beda yang telah ditentukan peneliti.

Analisis proses belajar yang dilakukan pada penelitian ini berdasarkan pengamatan yang dilakukan oleh peneliti saat proses pembelajaran di kelas selama penelitian berlangsung. Pembelajaran menggunakan model Problem Based Learning dengan pendekatan saintifik terdiri dari beberapa langkah. Sebelum memulai langkah-langkah yang ada pada model pembelajaraan Problem Based Learning, guru memberikan simulasi

Hesti, Hanifah, Syafdi 
model pembelajaran yang akan diterapkan terlebih dahulu kepada peserta didik.

Model pembelajaran Problem Based Learning dengan pendekatan saintifik terdiri dari beberapa langkah. Langkah pertama pada model pembelajaran Problem Based Learning adalah guru memberikan LKPD yang diberikan kepada masing-masing kelompok sebagai bahan pelajaran pada proses pembelajaran di kelas yang menggunakan model pembelajaran Problem Based Learning.

Langkah kedua Guru menjelaskan tujuan pembelajara dan aktivitas yang akan dilakukan. Guru mengajukan suatu masalah sebagai langkah awal pembelajaran. Masalah yang diajukan biasanya masalah dalam dunia nyata. Guru memotivasi peserta didik untuk terlibat aktif dalam pemecahan masalah.

Langkah ketiga Mendorong peserta didik untuk mengumpulkan informasi sebanyak-banyaknya. Peserta didik melakukan penyelidikan dan investigasi dalam rangka menyelesaikan masalah. Guru membimbing setiap kelompok agar menemukan jawaban yang benar dari persoalan yang ada namun tidak memberi jawaban.

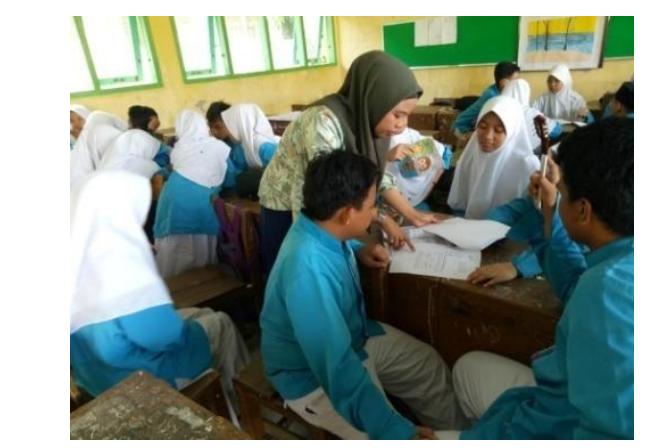

Gambar 1. Aktivitas Peserta didik pada tahap Diskusi Kelompok LKPD

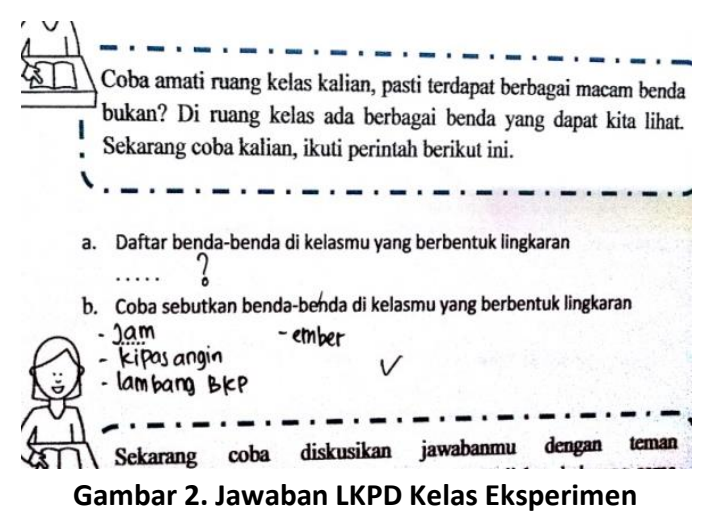

Gambar 2 merupakan jawaban dari salah satu kelompok pada sub materi unsur-unsur. Terlihat pada gambar 2 bahwa peserta didik telah dapat memberikan jawaban soal dengan benar namun peserta didik tidak menuliskan daftar-daftar benda dikelas. Pada langkah ini peserta didik berperan besar dalam membangun sendiri pemahamannya bersama kelompok. Pada pertemuan pertama sampai pertemuan keenam, peserta didik antusias dengan pembelajaran bersama kelompok.

Langkah ke empat Guru memilih kelompok untuk mempresentasikan hasil pemikiran kelompoknya di depan kelas. Guru bertanya apakah setiap kelompok setuju dengan hasil pemikiran kelompok yang maju. Guru meminta kelompok yang tidak setuju untuk mengemukakan hasil pemikiran yang menurutnya benar.

Tahap terakhir Guru dan peserta didik menganalisis dan mengevaluasi terhadap pemecahan masalah yang dipresentasikan setiap kelompok. Peserta didik melakukan tanya jawab dan diskusi terkait kegiatan penyelesaian masalah yang telah dilakukan. Guru bersama peserta didik membuat kesimpulan dan refleksi atas materi yang dipelajari. Selanjutnya peneliti memilih salah satu kelompok untuk maju ke depan menjelaskan hasil diskusi kelompoknya tentang jawaban soal yang dianggap susah pada LKPD.

Hesti, Hanifah, Syafdi 
Kelompok lain dipersilahkan mengomentari atau memberi masukan tentang hasil kerja kelompok yang maju. Pada pelaksanaan diskusi kelas di pertemuan awal, kelompok yang maju masih ragu dan malu menyampaikan hasil diskusi di depan kelas karena peserta didik tidak terbiasa berbicara di depan kelas. Pada pertemuan selanjutnya, peserta didik mulai terbiasa untuk hasil diskusi di depan kelas. Guru bersama peserta didik menyimpulkan materi yang dipelajari diakhir pelajaran.

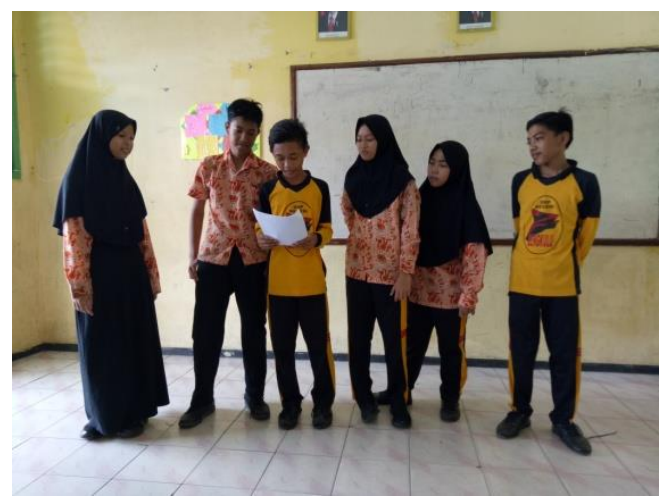

Gambar 3. Aktivitas Peserta didik pada Tahap Persentasi Hasil Diskusi

Berdasarkan analisis proses belajar peserta didik pada kelas yang menggunakan model pembelajaran Problem Based Learning dengan pendekatan saintifik terlihat bahwa proses belajar dengan menggunakan model pembelajaran Problem Based Learning dengan pendekatan saintifik peserta didik lebih antusias dan lebih aktif dalam proses belajar dengan menggunakan kelompok.

Sependapat menurut Arends dalam Hosnan (2016:295) model Problem-Based Learning (PBL) adalah model pembelajaran dengan pendekatan pembelajaran peserta didik pada masalah autentik sehingga peserta didik dapat menyusun pengetahuan mereka sendiri, menumbuhkembangkan keterampilan yang lebih tinggi dan inquiry, memandirikan peserta didik dan meningkatkan percaya diri.
Tabel 2. Rekap Rata-rata Nilai LKPD Tiap Pertemuan

\begin{tabular}{|c|c|}
\hline \multirow{2}{*}{ Pertemuan } & $\begin{array}{c}\text { Rata-Rata Nilai } \\
\text { LKPD }\end{array}$ \\
\cline { 2 - 2 } & PBL \\
\hline 1 & 88,25 \\
\hline 2 & 87,32 \\
\hline 3 & 89,69 \\
\hline 4 & 91,89 \\
\hline 5 & 90,01 \\
\hline 6 & 90,65 \\
\hline
\end{tabular}

Berdasarkan tabel 2, terlihat bahwa rata-rata nilai LKPD tiap pertemuan pada kelas yang menggunakan model pembelajaran Problem-Based Learning berada di atas nilai KKM. Nilai rata-rata LKPD pada kelas yang menggunakan model pembelajaran PBL yaitu 89,63 .

Tabel 3 Rata-rata Nilai Tes

\begin{tabular}{|l|c|}
\hline \multicolumn{1}{|c|}{ Deskritif } & Nilai \\
\hline Jumlah Siswa & 34 \\
\hline $\begin{array}{l}\text { Jumlah Nilai } \\
\text { Siswa }\end{array}$ & 2875,25 \\
\hline Rata-rata & 84,57 \\
\hline Nilai Tertinggi & 94,06 \\
\hline Nilai Terendah & 49,50 \\
\hline
\end{tabular}

Berdasarkan tabel 2, terlihat bahwa rata-rata nilai tes pada kelas yang menggunakan model pembelajaran ProblemBased Learning berada di atas nilai KKM. Nilai rata-rata LKPD pada kelas yang menggunakan model pembelajaran PBL yaitu 84,57 .

Model pembelajaraan Problem-Based Learning memberikan kesempatan kepada peserta didik untuk memahami materi secara berkelompok. Model pembelajaran ProblemBased Learning pembelajaran berlandaskan masalah-masalah yang menuntut peserta didik mendapat pengetahuan yang penting, serta

Hesti, Hanifah, Syafdi 
memiliki strategi belajar sendiri dan kemampuan dalam berpartisipasi di dalam kelompok.

Arends dalam Hosnan (2016:295) model Problem-Based Learning (PBL) adalah model pembelajaran dengan pendekatan pembelajaran peserta didik pada masalah autentik sehingga peserta didik dapat menyusun pengetahuannya sendiri, menumbuhkembangkan keterampilan yang lebih tinggi dan inquiry, memandirikan peserta didik dan meningkatkan percaya diri.

Hasil belajar peserta didik menggunakan model Problem-Based Learning dapat membantu peserta didik meningkatkan hasil belajar peserta didik menjadi lebih baik. Hal tersebut mendukung penelitian yang dilakukan oleh Santoso (2017) yang menunjukkan bahwa ada pengaruh yang signifikan antara pendekatan scientific dengan model pembelajaran problem based learning terhadap hasil belajar matematika pada materi himpunan peserta didik kelas VII SMP Muhammadiyah 47 Sunggal.

\section{PENUTUP}

\section{KESIMPULAN}

Berdasarkan penelitian yang telah dilakukan pada peserta didik kelas VIII SMPN 2 Kota Bengkulu pada materi lingkaran dapat disimpulkan adanya pengaruh model Pembelajaran Problem Based Learning (PBL) dengan pendekatan saintifik terhadap hasil belajar peserta didik kelas VIII SMPN 2 Kota Bengkulu dengan nilai rata-rata hasil perhitungan pengujian hipotesis dengan menggunakan Uji-t menyatakan bahwa nilai $t_{\text {hitung }}=2,402$, dan $t_{\text {tabel }}=1.996$ dengan taraf signifikan 5\%. Nilai rata-rata tes akhir untuk kelas eksperimen adalah 84,57 sedangkan nilai rata-rata tes akhir kelas kontrol adalah 79,69.

\section{SARAN}

Saran yang dapat peneliti berikan berdasarkan penelitian yang telah dilakukan adalah:

1. Guru selalu mengingatkan peserta didik agar menuliskan satuan luas dan satuan panjang pada saat melakukan penyelesaian masalah serta mengingatkan peserta didik agar terbiasa menyelesaikan permasalahan dengan mengikuti langkah-langkah yang diminta yaitu menuliskan diketahui, ditanya dan jadi.

2. Untuk guru selalu mengingatkan peserta didik agar terbiasa menyelesaikan permasalahan dengan mengikuti langkah-langkah yang diminta yaitu menuliskan diketahui, ditanya dan jadi.

3. Peserta didik diminta untuk menyiapkan alat bantu seperti jangka, busur dan penggaris sejak beberapa hari sebelum pembelajaran berlangsung. Selain itu guru juga sebaiknya membawa cadangan alat bantu sebagai alternatif apabila terdapat peserta didik yang tidak membawa alat bantu tersebut.

4. Guru mengkondisikan peserta didik untuk disiplin dengan menegaskan dan menegur secara keras serta langsung menunjuk peserta didik yang ribut untuk menjelaskan materi yang dipelajari.

5. Setiap kegiatan dan tahap dalam pembelajaran diberikan petunjuk lengkap dan jelas agar peserta didik tidak selalu bertanya kepada guru tentang apa yang harus dikerjakan secara berulang. 


\section{DAFTAR PUSTAKA}

Hosnan, M. (2016). Pendekatan Saintifik dan Kontekstual dalam Pembelajaran Abad 21. Bogor: Galia Indonesia

Hudojo, Herman. (2005). Pengembangan Kurikulum dan Pembelajaran Matematika. Malang: IKIP Malang

Jihad, Asep dan Abdul Haris. (2013). Evaluasi Pembelajaran.Yogyakarta: Multi Pressindo

Lestari, Karunia Eka dan Mokhammad Ridwan Yudhanegara. (2015). Penelitian Pendidikan Matematika. Bandung: PT Refika Aditama

Sani, R. A. (2015) . Pembelajaran Saintifik Untuk Implementasi Kurikulum 2013. Jakarta : PT Bumi Aksara.

Santoso, Fatma Erya. (2017). Pengaruh Pendekatan Scentific dengan Model Pembelajaran Problem Based Learning terhadap Hasil Belajar Matematika Siswa Kelas VII SMP Muhammadiyah 47 Kecamatan Sunggal. Jurnal tidak diterbitkan. Universitan Medan

Shoimin, Aris. (2014). 68 Model Pembelajaran Inovatif dalam Kurikulum 2013. Yogyakarta: Ar-Ruzz Media.

Salinan Peraturan Pemerintah RI Nomor 32 Tahun 2013. Perubahan atas Peraturan Pemerintah Nomor 19 Tahun 2005 tentang Standar Nasional Pendidikan.

Soedjadi. (2000). Kiat Pendidikan Matematika di Indonesia Konstatasi Keadaan Masa Kini Menuju Harapan Masa Depan. Jakarta: Direktorat Jenderal Pendidikan Tinggi

Sugiyono. (2017). Statistika Untuk Penelitian.

Bandung : Alfabeta
Yudhanegara, M. R, dan Lestari, K.E. (2017). Penelitian Pendidikan Matematika. Bandung: Refika Aditama 